\title{
Optimisation through offshore - between reality and legality
}

\author{
Bianca Cristina Ciocanea ${ }^{11}$, Ioan Cosmin Pițu ${ }^{2}$, Paraschiva Mihaela Luca $^{3}$, and Dragoș \\ Mihai Ungureanu ${ }^{4}$ \\ ${ }^{1}$ Lucian Blaga University of Sibiu, Department of Doctoral Studies B-dul Victoriei Street 20, Sibiu, \\ Romania \\ ${ }^{2}$ Lucian Blaga University of Sibiu, Department of Doctoral Studies B-dul Victoriei Street 20, Sibiu, \\ Romania \\ ${ }^{3}$ Lucian Blaga University of Sibiu, Department of Doctoral Studies B-dul Victoriei Street 20, Sibiu, \\ Romania \\ ${ }^{4}$ Spiru Haret University, Bucharest România
}

\begin{abstract}
The study highlights the complete image of the characteristics regarding offshore areas, by taking into account the perspective to deploy new measures of fiscal transparency. The importance of such areas stems from the fact that world economies lose important sums of money, every year by default of taxes. This happens as a consequence of corporative international abuse of fiscal evasion and the relocation of the profit made by big companies. The sums resulted from erosion of national taxation bases, from fiscal evasion and fraud and other infringements connected with fiscal evasion (are often being transferred to offshore companies so that their illegal characteristics gets lost and after that to be reintroduced into the economic cycle. The main characteristics of these offshore centres is lack of transparency and cooperation with foreign authorities, fiscal and banking secrecy being considered the guarantee of the offshore areas, measurable variables, fleshes in indicators that reflect the secret degree for each state. Therefore, fighting against such practicies through offshore societies aims at enforcing some measures to enlarge transparency and for the regions do not cooperate there is no granting of fiscal deductibility for transactions that entail the transfer of sums to the respective regions.
\end{abstract}

Key words: offshore companies, transparency, taxes, fiscal evasion, tax havens

\section{Introduction}

A subject of significant importance, at an international level, mainly for investors and entrepreneurs but for the state too as guarantor of regulations enforced by free economy, tax havens play important roles on the stage of capital movements as well as of among states;

${ }^{1}$ Corresponding author: sb19biu/@gmail.com 
also among multinationals or rich people, being very often part of some interactions networks for transactions that are not transparent at all.

The coming into being of tax havens is the result of several factors, an economic necesity linked with a system of profound capitalist and liberal thinking, their appearance is meant to be a result to the demand of the market. With no natural resources, tax havens ensure the economic smooth running withinn the sector of services.

The lack of resources does not provide an environment favorable to industry or agriculture so services are the ones that can ensure economic growth.[1] States that choose to offer a relaxed financial regime do so in order to provide the market with a financial service, the outcome being to attracttive investment and development at the local level. On one side this thing can be looked uppon as a way to prosper from an economic point of view, regarding some states where the legislation tallies with the investors demand and the competitional rigours of the market. On the other side, transactions and goods that want to be hidden from taxes find refuge in places where the laws, economic stability, culture, customs and traditions and mostly of the time the stimulations are arranged and work in such a way that to provide a favorable environment for cutting of tax burdens.

Understanding the term "tax haven" and how offshore mechanisms work facilitates the understanding of the current behavior of major financial players in the global market for tax optimization, as well as the role of tax havens and offshore centers in the global chain. The genesis of the notion of tax haven is found in English, the term coming from tax-haven, which means refuge, shelter or even tax port. Studying the specialized doctrine we find that defining the tax haven is a task at least as difficult as the identification of their users, some authors even considering that "there are as many definitions as the number of tax havens" [2]

According to the OECD, a tax haven is in the classic meaning, a state where taxes are minimal or non-existent. The territory is used by corporations in order to avoid the taxes and duties that the corporation would owe in states with higher levels of taxation. The OECD report attributes to tax havens a number of key features such as: total lack of taxes or the existence of nominal taxes, inefficient exchange of information, opacity on the implementation and functioning of legislative, legal or administrative provisions.[3]

By transposing the characteristics that OECD attributed to the tax haven, we can define it in a general way as being a territory that offers persons and feregn firms trust and legislative and economic stability, zero fiscal responsibility; these are much redused as compared to the origin country within the context in which financial information regarding transactions are not transparent and therefore foreign fiscal authorities have no access either at all or in a very limited way.

From a fiscal perspective the tax haven is being defined as a territory of a state or part of it where there are fiscal facilities such as: no taxation, low cost of taxations only on certain categories of goods, gains and activities, quaranteeing banking secrecy, no restriction regarding currency transactions and this is an easy way to set up companies.[4]

Tax havens play both a positive and a negative role in the functioning of societies and economies. Tax havens arise even as a result of the demand mechanism- supply, the tax motivations for the use of these instruments are varied. For example, there are tax planning transactions that take place within the limits of the law in tax havens. However, tax havens are also used as means of international tax evasion.

\section{Literature review}

Assuming that any investor is looking for ways to pay taxes as low as possible, or why not, he is tempted not to pay at all, in order to protect his wealth, certain territories have taken profit of this weakness and legislated a legal framework favorable to attracting financial investments by providing facilities and tax exemptions, thus facilitating the choice and use 
of tax optimization schemes. Thus, the author Giurea defines the "tax havens ", as " being any financial area that does not charge taxes or fees are reduced on all or only on certain categories of income, a high level of banking or commercial secrecy, minimum requirements on the part of the central bank and no restrictions on currency exchange". [5]

Specialized literature emphasizes that tax havens are, in fact, a strategy developed only by those states to which this financial vehicle suits. What makes them develop such strategies? First of all, the lack of financial, human, material resources make them a target for investors who aims at the surplus of the rent obtained from the taxation of income that would be much more expensive in another jurisdiction. So, the tax haven aspires in the first phase to the status of an offshore center. According to Roxana Maria Chireac, the notion of tax haven is included in that of an offshore financial center, nor on their definition after there but there isn $t$ an accepted setting on defining them, the first notion reflecting pejorative accents due to the association of tax haven with phenomena such as money laundering, corruption, illegal trade, drug trafficking or unloyal competition. [6]

A first feature of tax havens and offshore financial centres is that they do not usually require residency or business presence for individuals and companies to benefit from their tax policies. [7]

The IMF assigns to offshore centres the most common characteristics: Minimum or zero taxation, moderate or light financial legal framework, the existent of banking secrecy- the main asset of tax havens acting as the main guarantor of the safety offered by tax havens, confidentiality and anonymity.

Tax havens are also characterized by political, social, fiscal, legislative stability, with a solid infrastructure (transport and communication means, accommodation facilities, developed hotel industry, and restaurants), as well as the competent human resource made up of banking and law professionals.

According to an OECD report drawn up with the aim of rejecting global tax competitiveness, entitled "Harmful tax competition - an emerging global problem"[8] privileged tax regimes identified by both doctrinaires and practitioners as offshore financial centres, is characterized by lack of effective taxation or modest taxation, limiting tax regimes enforced to certain operations or taxpayers- only to non-residents, lack of transparency of financial institutions and exchange of information .

The large fiscal burden, in conjunction with a burden some legislative framework, causes international commercial companies to choose the variant of tax optimization, more precisely the alternative of states with relaxed taxation, characterized primarily by a level of taxation, or non-existent, the Vanuatu case. A second feature of offshore centers is the orientation towards international financial flows. All this is possible by the existence of a legal tax framework.

Regarding banking secrecy, one of the most important assets of offshore companies and a basic feature of tax havens, requires observance by bankers and banking institutions of legal provisions prohibiting them from disclosing information about transactions, and their customers either they had access to them in terms of transactions, or they obtained them from customers or from third parties. This duty is similar to maintaining the professional secrecy that must be respected by those who carry out liberal processes such as lawyers or notaries. Luxembourg punishes the disclosure of bank secrecy with imprisonment and Switzreland, one of the first states to regulate bank secrecy, serves as a model for most tax havens that have similar aspect.

The autors Hansen și Kessler (2001)[9] found that the existing and the characteristics of the tax havens are determined by a combination of geographical and political factors. Their research focused on how geographical position influences the pattern of taxation.

They investigated whether the geography of the state affects taxation, research results highlightened that the coming into being of tax havens is related to the difference in size of 
states and, perhaps the most relevant observation that has resulted, was that states with smallarea have less taxes than larger states. Hanssen and Kessler, Slemrod and Wilson (2009)[10] outlined that smaller countries usually choose, to become tax havens by offering a more permissive legislative framework and reduced taxation.

According to the exchange of the transparency criterion regarding the free exchange of information, in 2013, the Tax Justice Network published the names of 82 states or territories whose legislation regarding secrecy met the most rigorous criteria according to which each state got a certain score.

The closer the score is to 100 , the stronger the banking secrecy and confidentiality in that jurisdiction. Key Financial Secrecy Indicators - (KFSI) is based on 20 key financial secrecy indicators for each country, each of which is rated out of 100 . The average score of the 20 indicators generates the country's secret score. One of the most important indicators reflects the performance of countries in the automatic exchange of information based on regulations on transparency, on ownership, and in relation to transparency od accounts for the public. [11] At the same time the indicators are based on criteria for compliance with the rules for preventing money laundering.

\section{Data and research methodology}

The conclusions of this study are based on the existing literature in the field, on the processing and data interpretation through data comparative analysis.

\section{Results and discussion}

In our research we considered relevant the presentation of indicators for European countries by comparing 2018 and 2020. The numerical data are presented by Tax Justice Network [12], in KFSI the 20 indicators are divided into 4 categories as follows: category 1 includes indicators that refer to banking secrecy and registration of entities, the second category on the transparency of the legal entity, category 3 includes 6 indicators on the integrity of tax and financial regulations and category 4 includes indicators refering to international cooperation and its standards through the exchange of information, bilateral treaties, indicators that also reflect the level of cooperation against money laundering and international legal cooperation.

Summarizing the 20 indicators of financial secrecy on the 4 categories, the score outcome of financial secrecy at European level is as follows: 
Table 1. The difference between FSI 2018 and FSI 2020

\begin{tabular}{|c|c|c|c|c|c|c|c|c|c|c|c|c|}
\hline \multirow[b]{2}{*}{ Jurisdiction } & \multicolumn{4}{|c|}{ FSI 2018 categories } & \multicolumn{4}{|c|}{ FSI 2020 categories } & \multicolumn{4}{|c|}{ Difference 2018-2020 } \\
\hline & $\begin{array}{l}\text { Cat } 1 \\
2018\end{array}$ & $\begin{array}{l}\text { Cat } 2 \\
2018\end{array}$ & $\begin{array}{l}\text { Cat 3 } \\
2018\end{array}$ & $\begin{array}{l}\text { Cat } 4 \\
2018\end{array}$ & $\begin{array}{l}\text { Cat 1 } \\
2020\end{array}$ & $\begin{array}{l}\text { Cat } 2 \\
2020\end{array}$ & $\begin{array}{l}\text { Cat } 3 \\
2020\end{array}$ & $\begin{array}{l}\text { Cat } 4 \\
2020\end{array}$ & Cat 1 & Cat 2 & Cat 3 & Cat 4 \\
\hline Lithuania & 47,6 & 85,0 & 36,3 & 13,8 & 51,4 & 85,0 & 44,6 & 14,1 & 3,8 & 0,0 & 8,3 & 0,4 \\
\hline Latvia & 73,2 & 85,0 & 50,4 & 13,5 & 70,0 & 82,5 & 58,8 & 16,9 & $-3,2$ & $-2,5$ & 8,3 & 3,4 \\
\hline Malta & 85,4 & 72,0 & 65,4 & 7,8 & 75,4 & 72,0 & 73,3 & 14,5 & $-10,0$ & 0,0 & 7,9 & 6,8 \\
\hline Cyprus & 77,5 & 90,0 & 55,4 & 13,8 & 77,0 & 83,0 & 62,1 & 12,3 & $-0,5$ & $-7,0$ & 6,7 & $-1,5$ \\
\hline United Kingdom & 68,6 & 45,0 & 41,3 & 7,9 & 67,4 & 55,0 & 47,1 & 7,4 & $-1,2$ & 10,0 & 5,8 & $-0,5$ \\
\hline Czechia & 48,5 & 70,0 & 66,7 & 16,5 & 56,3 & 70,0 & 69,2 & 15,4 & 7,8 & 0,0 & 2,5 & $-1,1$ \\
\hline Bulgaria & 70,5 & 65,0 & 61,3 & 9,6 & 56,0 & 52,0 & 66,3 & 12,9 & $-14,5$ & $-13,0$ & 5,0 & 3,3 \\
\hline Estonia & 60,8 & 73,0 & 49,2 & 13,3 & 43,8 & 54,5 & 52,9 & 13,0 & $-17,0$ & $-18,5$ & 3,7 & $-0,3$ \\
\hline Ireland & 60,3 & 68,0 & 53,3 & 12,9 & 60,3 & 57,0 & 55,8 & 10,4 & 0,0 & $-11,0$ & 2,5 & $-2,5$ \\
\hline Netherlands & 89,0 & 80,0 & 67,5 & 17,6 & 89,0 & 82,5 & 70,0 & 17,6 & 0,0 & 2,5 & 2,5 & 0,0 \\
\hline Belgium & 61,4 & 45,0 & 48,8 & 13,9 & 52,0 & 60,0 & 49,6 & 10,9 & $-9,4$ & 15,0 & 0,8 & $-3,0$ \\
\hline Portugal & 67,4 & 85,0 & 49,6 & 8,5 & 67,4 & 80,0 & 50,0 & 10,9 & 0,0 & $-5,0$ & 0,4 & 2,4 \\
\hline Luxembourg & 80,0 & 70,0 & 55,8 & 19,8 & 76,0 & 62,5 & 56,3 & 19,8 & $-4,0$ & $-7,5$ & 0,4 & 0,0 \\
\hline Sweden & 53,4 & 70,0 & 41,3 & 11,3 & 53,4 & 72,5 & 41,3 & 9,0 & 0,0 & 2,5 & 0,0 & $-2,3$ \\
\hline Finland & 70,6 & 70,0 & 47,5 & 16,5 & 68,4 & 72,5 & 47,5 & 13,3 & $-2,2$ & 2,5 & 0,0 & $-3,3$ \\
\hline Germany & 86,5 & 75,0 & 51,7 & 16,1 & 62,0 & 72,0 & 50,0 & 16,1 & $-24,5$ & $-3,0$ & $-1,7$ & 0,0 \\
\hline Italy & 57,4 & 63,0 & 57,1 & 11,3 & 57,4 & 70,5 & 55,4 & 8,9 & 0,0 & 7,5 & $-1,7$ & $-2,4$ \\
\hline Austria & 78,9 & 65,0 & 51,3 & 22,8 & 82,5 & 75,0 & 49,6 & 11,3 & 3,6 & 10,0 & $-1,7$ & $-11,5$ \\
\hline Hungary & 74,0 & 75,0 & 46,3 & 17,9 & 74,8 & 75,0 & 44,6 & 14,9 & 0,8 & 0,0 & $-1,7$ & $-3,0$ \\
\hline Poland & 65,6 & 90,0 & 48,8 & 19,1 & 65,6 & 85,0 & 47,1 & 18,9 & 0,0 & $-5,0$ & $-1,7$ & $-0,3$ \\
\hline France & 73,3 & 60,0 & 52,9 & 12,3 & 65,8 & 62,5 & 51,3 & 12,3 & $-7,5$ & 2,5 & $-1,7$ & 0,0 \\
\hline Slovenia & 39,9 & 65,0 & 42,1 & 14,9 & 34,4 & 56,0 & 40,4 & 14,1 & $-5,5$ & $-9,0$ & $-1,7$ & $-0,8$ \\
\hline Slovakia & 51,5 & 70,0 & 66,7 & 22,6 & 48,0 & 65,0 & 60,8 & 22,1 & $-3,5$ & $-5,0$ & $-5,8$ & $-0,5$ \\
\hline Greece & 67,0 & 85,0 & 51,7 & 21,9 & 56,0 & 85,0 & 47,5 & 9,9 & $-11,0$ & 0,0 & $-4,2$ & $-12,0$ \\
\hline Romania & 76,7 & 85,0 & 70,8 & 19,3 & 71,7 & 85,0 & 66,7 & 17,3 & $-5,0$ & 0,0 & $-4,2$ & $-2,0$ \\
\hline Spain & 56,4 & 80,0 & 40,8 & 6,8 & 57,4 & 72,5 & 35,0 & 4,9 & 1,0 & $-7,5$ & $-5,8$ & $-1,9$ \\
\hline Denmark & 77,0 & 70,0 & 41,3 & 16,9 & 59,8 & 72,5 & 31,3 & 14,4 & $-17,2$ & 2,5 & $-10,0$ & $-2,5$ \\
\hline
\end{tabular}

Source: Tax Justice Network database

Cat $12018 \longrightarrow$ Cat 12020

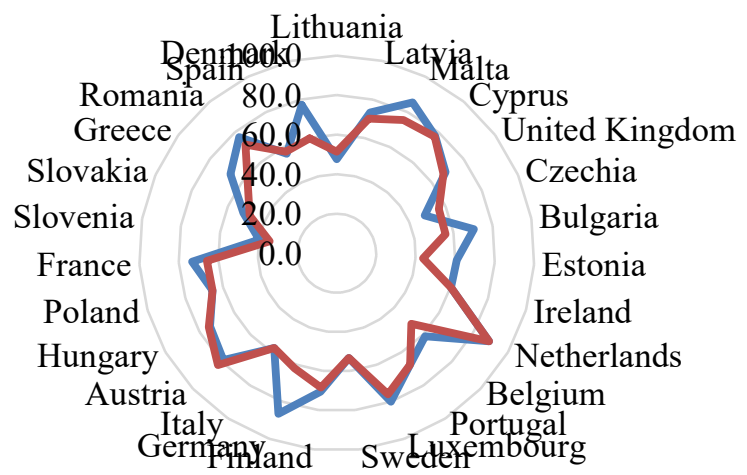

Fig.1 Cat 1 of Indexes - Evolution (2018 vs 2020) for UE member states. Bank secrecy and registered entieties.

Source: realized by the author based on Tax Justice Network data 
Analizing the graph, we notice a strong emphasis on the law of Netherlands, which confirms the opinions of doctrinaires that the banking system in this country is at least "mysterious". The score determined by the average of the first 5 indicators is very high (tends to 90), without fluctuations from one year to another. The tax legislation of Netherlands stipulates for reductions for withholding taxes in the case of dividends, but also for duties and interests paid to resident entities. Tax facilities also include the exemption from taxation of a large part of the capital gains resulting from the sale of shares in the jurisdictions of origin. Netherlands has developed an extensive structure of investment treaties, comprising almost 100 judgments, with Dutch companies having acces to this network which offers investors protection in terms of expropriation. The network provides equal treatment with third-country investors. The judiciary and Netherlands have dispute settlement clauses that allow for international arbitration, thus blocking the intervention of foreign gouvernments.

Category 1 of indicators, although decreasing in 2020 compared to 2018, also places Malta on top of the most advantageous states in terms of tax optimization, being considered as one of the most advantageous tax havens for residents, a condition that involves investments of approx. 1 mil euro, the incomes obtained abroad being non-taxed.

Category 1 of indicators gives Austria a top place in banking secrecy and in the preferences of tax haven users, with the average of the top 5 indicators rising slightly in 2020 as compared to 2018. Its position within the European Union and, of course, the political stability in this country have made Austria an attractive place for money of doubtful origins. The media noted in 2019 that money of doubtful origin from Soviet countries ended up in Austrian banks. Austria was at the center of the Cumex tax scandal. For the investigations into the ewift trading of shares in Austria and Luxembourg with a in order to obtain double refunds of dividend taxes are still ongoing. Another example is the revocation by the European Central Bank, in 2019, of the banking license of Anglo Austrian Bank for violating the rules on money laundering, about 500 million euros being channeled from former Soviet states to offshore companies.

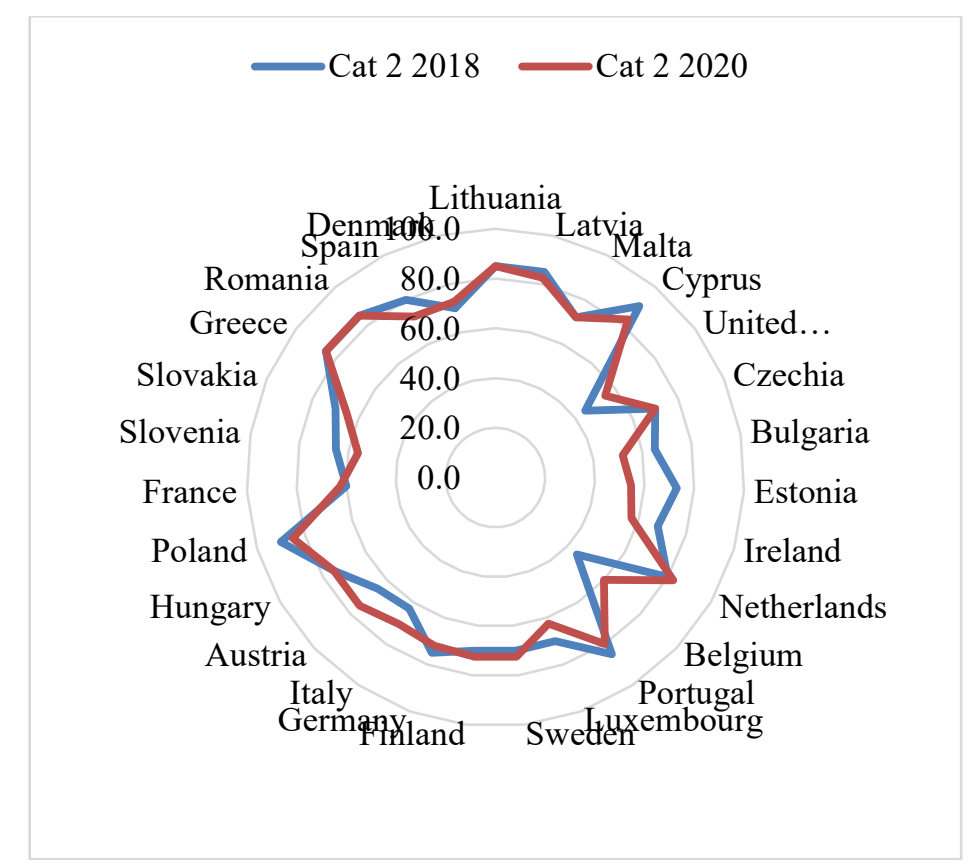

Fig.2 Cat 2 of Indexes - entities fiscal transparency- Evolution (2018 vs 2020) for UE member states.

Source: realized by the author based on Tax Justice Network data 
For the second category of indicators we notice stronger accentuations in 2018 compared to 2020 from countries like Poland, Cyprus or Portugal, while at the opposite pole are the Czech Republic and Belgium which bring during the two years $(2019,2020)$ consistent improvements.

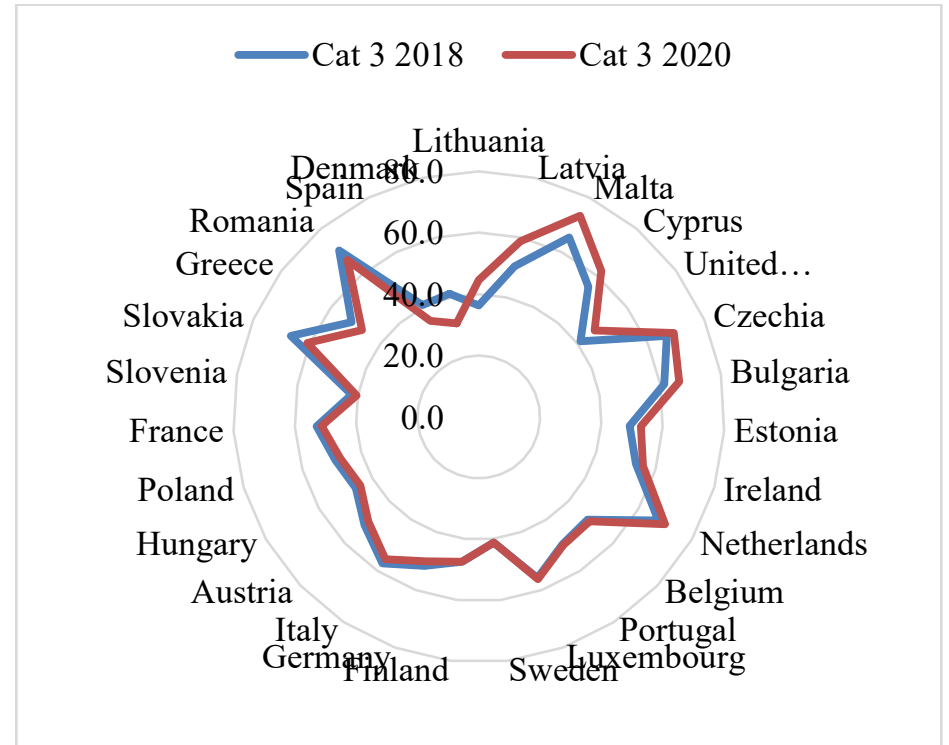

Fig.3 Cat 3 of Indexes - fiscal and financial integrity- Evolution (2018 vs 2020) for UE member states.

Source: realized by the author based on Tax Justice Network data

Category 3 of indexes regarding integrity of fiscal adjustments show increases for both Netherlands and Malta. They set Romania on top of among states with troublesome legislations, this means that in Romania they allow a greater fiscal optimisation.

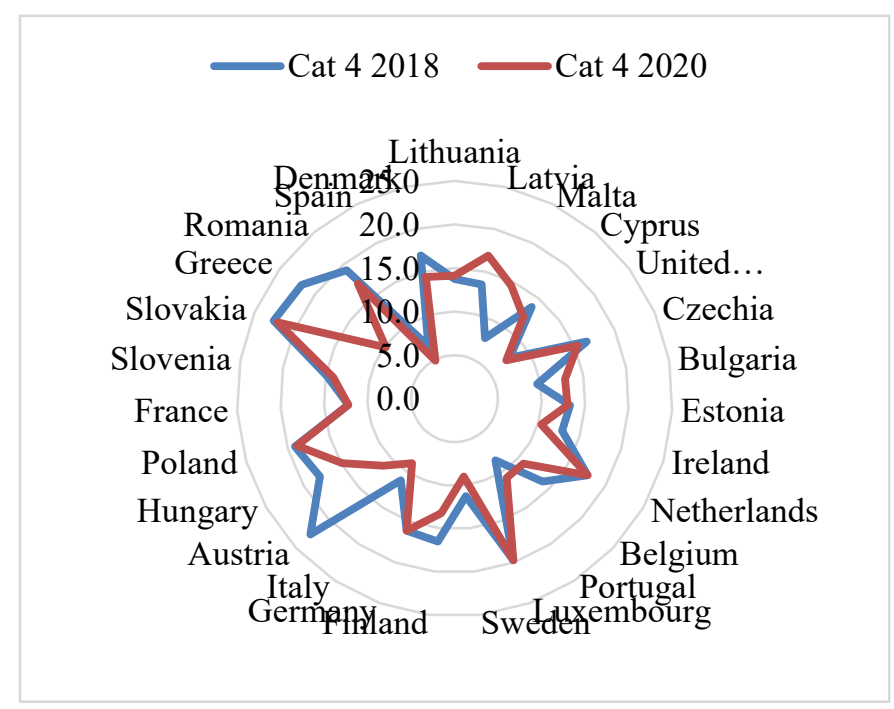

Fig.4 Cat 4 of Indexes - international cooperation- Evolution (2018 vs 2020) for UE member states.

Source: realized by the author based on Tax Justice Network data 
The analysis of financial secrecy scores at global level shows that most of the improvements following the adapted reforms, have taken place in the sphere the automatic exchange information and on the line of transparency property registration. According to The State of Tax Justice 2020, three important reform domains, so called „ABC-s” of fiscal justice, have been lately, the main targets of the military forces financial experts and decision makers at a global level. [12]

"Secret jurisdictions" as they are called by Tax Justice Network, uses as the main instrument Financial Secrecy Index, thus facilitating for any kind of entities, regardless of the corporate form, to circumvent the legislation, to undermine the regulations of other states and to not comply with rules. FSI is the most relevant, highly compex index which reflects both the level of secrecy of financial centers and the impact of secrecy on financial flow all around the world.

Trade societies often look for fiscal optimisation techniques in order to relocate the gains in jurisdiction with more relaxed taxation. Profit relocation aims to avoid higher taxation of economic activity. Using the financial power, their size and their international presence, multinationals have always been tempted not to pay taxes, so they have always sought solutions to concentrate profits in countries with relaxed taxation and tax havens. In order, to have a clear picture of the jurisdictions that provide multinationals with the necessary tools to evade taxes the corporate tax haven index [13]- CTHI - is used.

A classification of the main tax havens from the perspective of multinationals is made with the help of CTHI. It has at it's bases the degree of aggresives and extention where the jurisdiction offers posibilities of avoiding tax payments in this way eroding the basis of taxation and diminishing the fiscal gains of other states at a world level. The index also offers an image on the degree that every state contributes to a global diminishing race of corporate gains.

The ranking made by Tax Justice Network is being launched every 2 years, the last was published in 2019. The index completes that of financial secrecy which classifies the tax havens according to the degree of the financial secrecy.

Table 2. CTHI ranking and global scale weight

\begin{tabular}{ccccc}
\hline Jurisdiction & $\begin{array}{c}\text { CTHI } \\
\text { Value }\end{array}$ & $\begin{array}{c}\text { CTHI } \\
\text { Share }\end{array}$ & $\begin{array}{c}\text { Haven } \\
\text { Score }\end{array}$ & $\begin{array}{c}\text { Global Scale } \\
\text { Weight }\end{array}$ \\
\hline British Virgin Islands & 2769 & $7,29 \%$ & 100 & $2,12 \%$ \\
\hline Bermuda & 2653 & $6,98 \%$ & 100 & $1,87 \%$ \\
\hline Cayman Islands & 2534 & $6,67 \%$ & 100 & $1,63 \%$ \\
\hline Netherlands & 2391 & $6,29 \%$ & 78 & $12,77 \%$ \\
\hline Switzerland & 1875 & $4,94 \%$ & 83 & $3,41 \%$ \\
\hline Luxembourg & 1795 & $4,73 \%$ & 72 & $10,53 \%$ \\
\hline Jersey & 1541 & $4,06 \%$ & 98 & $0,43 \%$ \\
\hline Singapore & 1489 & $3,92 \%$ & 81 & $2,12 \%$ \\
\hline Bahamas & 1378 & $3,63 \%$ & 100 & $0,26 \%$ \\
\hline Hong Kong & 1372 & $3,61 \%$ & 73 & $4,38 \%$ \\
\hline Ireland & 1363 & $3,59 \%$ & 76 & $3,12 \%$ \\
\hline United Arab Emirates & 1245 & $3,28 \%$ & 98 & $0,22 \%$ \\
\hline United Kingdom & 1068 & $2,81 \%$ & 63 & $7,30 \%$ \\
\hline
\end{tabular}




\begin{tabular}{|c|c|c|c|c|}
\hline Mauritius & 950 & $2,50 \%$ & 80 & $0,65 \%$ \\
\hline Guernsey & 891 & $2,35 \%$ & 98 & $0,09 \%$ \\
\hline Belgium & 822 & $2,17 \%$ & 68 & $1,83 \%$ \\
\hline Isle of Man & 804 & $2,12 \%$ & 100 & $0,05 \%$ \\
\hline Cyprus & 698 & $1,84 \%$ & 71 & $0,73 \%$ \\
\hline China & 659 & $1,73 \%$ & 58 & $3,67 \%$ \\
\hline Hungary & 561 & $1,48 \%$ & 69 & $0,49 \%$ \\
\hline Curacao & 552 & $1,45 \%$ & 72 & $0,32 \%$ \\
\hline France & 525 & $1,38 \%$ & 56 & $2,81 \%$ \\
\hline Malta & 519 & $1,37 \%$ & 74 & $0,22 \%$ \\
\hline Germany & 461 & $1,21 \%$ & 52 & $3,32 \%$ \\
\hline USA & 408 & $1,07 \%$ & 43 & $12,89 \%$ \\
\hline Panama & 405 & $1,07 \%$ & 72 & $0,13 \%$ \\
\hline Spain & 403 & $1,06 \%$ & 55 & $1,53 \%$ \\
\hline Gibraltar & 398 & $1,05 \%$ & 66 & $0,28 \%$ \\
\hline Sweden & 365 & $0,96 \%$ & 56 & $0,90 \%$ \\
\hline Italy & 302 & $0,79 \%$ & 51 & $1,28 \%$ \\
\hline Czech Republic & 270 & $0,71 \%$ & 59 & $0,23 \%$ \\
\hline Turks and Caicos Islands & 265 & $0,70 \%$ & 100 & $0,00 \%$ \\
\hline Austria & 258 & $0,68 \%$ & 52 & $0,66 \%$ \\
\hline Finland & 237 & $0,62 \%$ & 55 & $0,29 \%$ \\
\hline Anguilla & 233 & $0,61 \%$ & 100 & $0,00 \%$ \\
\hline Denmark & 226 & $0,60 \%$ & 52 & $0,44 \%$ \\
\hline Liechtenstein & 224 & $0,59 \%$ & 70 & $0,03 \%$ \\
\hline Lebanon & 221 & $0,58 \%$ & 73 & $0,02 \%$ \\
\hline Estonia & 211 & $0,56 \%$ & 67 & $0,04 \%$ \\
\hline Monaco & 207 & $0,54 \%$ & 68 & $0,03 \%$ \\
\hline Latvia & 197 & $0,52 \%$ & 68 & $0,02 \%$ \\
\hline South Africa & 184 & $0,48 \%$ & 47 & $0,54 \%$ \\
\hline Romania & 178 & $0,47 \%$ & 56 & $0,11 \%$ \\
\hline Seychelles & 163 & $0,43 \%$ & 68 & $0,01 \%$ \\
\hline Bulgaria & 144 & $0,38 \%$ & 56 & $0,06 \%$ \\
\hline Macao & 144 & $0,38 \%$ & 57 & $0,05 \%$ \\
\hline Slovakia & 136 & $0,36 \%$ & 53 & $0,08 \%$ \\
\hline Croatia & 127 & $0,33 \%$ & 55 & $0,05 \%$ \\
\hline Portugal & 127 & $0,34 \%$ & 46 & $0,23 \%$ \\
\hline Taiwan & 120 & $0,32 \%$ & 47 & $0,16 \%$ \\
\hline Andorra & 109 & $0,29 \%$ & 69 & $0,00 \%$ \\
\hline Lithuania & 107 & $0,28 \%$ & 55 & $0,03 \%$ \\
\hline Poland & 98 & $0,26 \%$ & 40 & $0,33 \%$ \\
\hline Aruba & 92 & $0,24 \%$ & 64 & $0,00 \%$ \\
\hline
\end{tabular}




\begin{tabular}{ccccc}
\hline Slovenia & 81 & $0,21 \%$ & 50 & $0,03 \%$ \\
\hline Botswana & 74 & $0,20 \%$ & 55 & $0,01 \%$ \\
\hline Liberia & 71 & $0,19 \%$ & 49 & $0,02 \%$ \\
\hline Kenya & 60 & $0,16 \%$ & 51 & $0,01 \%$ \\
\hline San Marino & 57 & $0,15 \%$ & 62 & $0,00 \%$ \\
\hline Ghana & 56 & $0,15 \%$ & 49 & $0,01 \%$ \\
\hline Greece & 54 & $0,14 \%$ & 39 & $0,07 \%$ \\
\hline Tanzania & 40 & $0,11 \%$ & 46 & $0,01 \%$ \\
\hline Gambia & 9 & $0,02 \%$ & 48 & $0,00 \%$ \\
\hline Montserrat & 7 & $0,02 \%$ & 65 & $0,00 \%$ \\
\hline
\end{tabular}

Source: Tax Network Justice database

According to data presented by Tax Network Justice reffered to index CTHI, on top tax havens mostly seen as bidders for multinationals British Virgin Islands, Cayman Islands, Switeland, Bahamas and Irland are being positioned.

The Virgin Islands are responsable of more than 16 bilion $\$$ loss due to the fact that global abuses of multinational corporations on profit taxation are allowed as well as private fiscal evasion of $3,8 \%$ of global losses. The main commercial trade partners of The Virgin Islands responsable of its vulnerability, are Hong Kong, China și Netherlands.

The British Virgin Islands, Bermuda, Cayman and Jersey, Man Island, Turks, Caicos and Guernsey stand first in rating the first 10 tax havens at a world level, according to CTHI index having the highest scores on corporate tax. Such jurisdictions all belonging to Great Britain, make up a genuine spider web to avoid taxation, and allow fiscal an financial activities open to the abuse of corporate global taxation.

Great Britain, Netherlands, Switzerland and Luxemburg are responsable for half of the world risks of corporate tax abuse, namely of a 47,6\% from a total of 245 billion $\$$ [14], and the cluster of states known as ,,axes of taxes avoidance". The report "Fiscal Justice Status 2020 " highlightens the movement of the profit towards multinational corporations through the ,axes of taxes evasion” it entails annual losses at a global level that surpasses 116 billion $\$$ that represents corporate taxes.

The "Fiscal Justice Status 2020" that $37,4 \%$ of global losses are the result of financial services that are being allowed by the spider web in Great Britain with it's over sea territories.[15]

A report of the American Senate, concerning Microsoft Company was presented as a case study, it optimizes the cost with $44 \%$ in 2011, and it confirms the fact that during 2011 the shisft on the profi multinationals in offshore centers by fiscal schemes in optimization entailed losses for the US no less than 1,7 trillion \$

\section{Conclusions}

Due the fast that the use of fiscal optimisation represents the main practical utility and very often within the legal limit concerning offshore companies, we consider that the only way for minimising the effects of this process is represented by stressing transparency, also we must identify new ways through which offshore companies should coerced to increase transparency.

Starting with the main characteristics, of an offshore namely, the fiscal and bank secrecy, relaxed fiscal environment and low taxes, the fight for debunking offshore mecanisms must 
be focussed mainly on international fiscal transparency in order to enforce taxation in home countries.

Such steps must be completed with not granting deductibilities for transactions with offshore. An important step would be the enforcement of taxation systems onshore for such transactions.

Taking in to account the spreading and crossborder nature of this phenomenon we conclude that the measures taken internally only cannot demonstrate efficiency or have even have an opposite effect by breaking up the unique market. Therefore, the approach of some coordinated and unitary measures taken at EU level are no doubt imperative.

\section{References}

1. D. Dharmapala, What Problems and Opportunities are created by Tax Havens? Oxford University Centre for Business Taxation, Working papers (2008)

2. R. Buziernescu., Paradisurile fiscale internationale

http://www.financejournal.ro/fisiere/revista/51725386828_BUZIERNESCU_RO.pdf

3. https://www.oecd.org/ctp/glossaryoftaxterms.htm

4. Ș. Minea. F.C Costaș., Fiscalitatea în Europa la începutul mileniului III, Ed.Rosetti, București p.274 (2006)

5. L. Giurea, Realizarea evaziunii fiscale legale și ilegale prin utilizarea firmelor off-shore şi paradisuri fiscale, Revista de investigare a criminalității nr.2/2012

6. R.M. Chireac, Societățile comerciale offshore - Între optimizare și evaziune fiscală, Ed.Hamangiu (2019)

7. https://www.investopedia.com/terms/t/taxhaven.asp

8. OCDE- Harmful Tax Competition -An Emerging Global Issue, Paris (1998)

9. N. S. Hansen, A. S. Kessler., The Political Geography of Tax H(e)avens and Tax Hells, American Economic Review (2001), vol. 91 (4), 1103-1115;

10. J. Slemrod, J. D. Wilson, Tax Competition with Parasitic Tax Havens, Journal of Public Economics, Elsevier, vol. 93 (11-12) (2009)

11. Tax Justice Network disponibil la https://www.taxjustice.net/press/financial-secrecy-index-2020reports-progress-on-global-transparency-but-backsliding-from-us-cayman-and-uk-prompts-callfor-sanctions/

12. https://fsi.taxjustice.net/en/explore

13. Financial Secrecy Index 2020, Narative Report on Austria disponibil https://fsi.taxjustice.net/PDF/Austria.pdf

14. Corporate Tax Haven Index https://www.corporatetaxhavenindex.org/en/

15. The State of Tax Justice 2020: Tax Justice in the time of COVID-19 November 2020 disponibil la https://taxjustice.net/wpcontent/uploads/2020/11/The_State_of_Tax_Justice_2020_ENGLISH.pd f 